\title{
USE OF DIFFERENT SPECTRAL VEGETATION INDICES TO DETERMINE THE PRESENCE OF MANTLED HOWLER MONKEYS (ALOUATTA PALLIATA G.) ON COCOA AGROSYSTEMS (THEOBROMA CACAO L.)
}

\author{
SÁNCHEZ-DÍAZ, B. ${ }^{1}$ - MATA-ZAYAS, E. ${ }^{1}$ - GAMA, L. ${ }^{1}$ - RULLAN-SILVA, C. ${ }^{1}$ - VIDAL-GARCÍA, F. ${ }^{2}$ \\ - RINCÓN-RAMÍREZ, J. ${ }^{3 *}$ \\ ${ }^{1}$ Universidad Juárez Autónoma de Tabasco, DACBiol, Villahermosa, Tabasco, México \\ ${ }^{2}$ Instituto de Ecología, Xalapa, Veracruz, México \\ ${ }^{3}$ Colegio de Postgraduados, Campus Tabasco, H. Cárdenas, Tabasco, México \\ *Corresponding author \\ e-mail: jrincon@colpos.mx
}

(Received $12^{\text {th }}$ Oct 2018; accepted $5^{\text {th }}$ Dec 2018)

\begin{abstract}
It is important to search for new strategies for biodiversity conservation. Recently, remote sensing has proven its usefulness due to the availability of presence and absence data of select species that can be modeled using different statistical designs. This research gathers data regarding the presence and absence of howler monkeys based on modeling studies, validated by sampling and field surveys. This kind of approach provides useful information that supports decision makers in their conservation efforts. The objective of this research is to identify the most robust spectral vegetation index through statistical analysis using mantled howlers (Alouatta palliata G.) as a model species, and different vegetation indices derived from satellite images. We compared certain phenological characteristics of the vegetation (leaf area index, biomass and high chlorophyll content of leaves) in the canopy of cocoa agrosystems (Theobroma cacao L.) both with and without howler monkey presence in Tabasco, Mexico. Data on the presence and absence of the species was obtained from agrosystems. Landsat-5 TM images of the agrosystem regions were used to calculate various vegetation indices. Statistical analysis software (SAS) was used to calculate statistically significant differences. A complete random design and two statistical models were applied - standard distances and Student's t-test - to compare the accuracy of vegetation indices. The Ratio Vegetation Index (RVI) had the greatest spectral separability and statistically significant difference on sites with and without the presence of the species in cocoa agrosystems. These indices could be taken as useful variables to predict habitats potentially suitable for the species in support of decision makers, and thus apply conservation efforts for primates.
\end{abstract}

Keywords: biodiversity conservation, remote sensing, RVI, satellite images, vegetation phenology

\section{Introduction}

The most promising applications of remote sensing in ecology refer to the fields of climate change, biodiversity conservation and ecosystem dynamics (Benayas, 1993; Turner et al., 2003; Kerr and Ostrovsky, 2003). In that sense, the ecological indicators frequently monitored are the changes in land cover, land use, ecological disturbance and vegetation phenology. Thus, remote sensing is one of the most powerful methods to map abiotic and biotic components of ecosystems (Wang et al., 2008; Rocchini et al., 2013; Avtar et al., 2016). Currently, climate change has a significant effect on all ecosystems leading to a loss of biodiversity regardless of direct human influence (Willis, 2015, Loreto et al., 2017). In this sense, the modeling plays an important role in alerting decision-makers to possible future risks (Bellard et al., 2012). Therefore, using remote sensing technologies helps us understand the possible trends of the 
impacts associated with climate change in space and time (Workie and Debella, 2018), and thus, support the development of strategies aiming to reduce those impacts on biodiversity. For example, one environmental characteristic to measure the impacts on vegetation is the plant phenology as a sensitive indicator of climate change and a direct measure of plant vitality (Zhao et al., 2013; Corbane et al., 2015). However, not all phenological changes are associated with climate change (Leong and Roderick, 2015), these could also be caused by pests or fire, among others. The phenological changes of plants can be detected through remote sensing by changes in vegetation spectral index values, to determine the availability of food for some mammals.

Undoubtedly, remote sensing technology is the only economically viable option to provide large-scale, long-term, standardized, full-coverage, high-resolution biodiversity observations (Turner et al., 2003; Skidmore et al., 2015; Lausch et al., 2015; Guo and Liu, 2018). Spectral vegetation indices are metrics derived from remote sensing that can be used to predict potential sites of species presence. These indices are useful to characterize and associate differences between vegetation types with certain phenological characteristics of the canopy, mainly related to vegetation cover parameters such as density, leaf area index and chlorophyll activity (Turner et al., 2015; Skidmore et al., 2015). Spectral reflectance varies with wavelength, healthy vegetation reflects more at certain lengths, especially the Red band (R), and Near Infrared (NIR). When vegetation suffers some kind of stress, such as the presence of pests or drought, the amount of water decreases in the cells. Since the Red band shows active chlorophyll absorption and NIR bands provide information on active chlorophyll reflectance, this difference in the spectral response makes it relatively easy to separate healthy vegetation from other coverings (Jensen, 2007; Genc et al., 2008; Chuvieco, 2016). These can also be used to identify certain changes on healthy vegetation behind cover or to detect differences associated with the presence of some mammal species. In addition, vegetation indices by spectral separability have been widely used in the identification of crops such as oil palm (Anaya and Valencia, 2013; Giraldo, 2017). Remote sensing does not impact biodiversity in a harmful way (Becerra, 2007). Some studies have used satellite images to study species occurrence, such as flamingo populations off Nalabana Island at Chilika Lake, India (Sasamal et al., 2008), emperor penguins on the continental coast of Antarctica (Fretwell et al., 2012), whale pathways through the New Gulf of the Valdes Peninsula in Argentina (Fretwell et al., 2014), gnus, zebras and gazelles in the East of the African Savannah (Yang et al., 2014; Xue et al., 2017), polar bears in the Canadian Arctic (Stapleton et al., 2014), elephant seals in the southern Pacific Ocean (McMahon et al., 2014) and albatrosses in the Bird Island to the west of mainland South Georgia (Fretwell et al., 2017). In this study, satellite images were used to determine the presence of an arboreal species, particularly ones that can be found in significantly transformed habitats, such as primates in cocoa agrosystems. Since the identification of animals in the canopy is difficult due to the resolution of available images, vegetation spectral indices can be used as an indirect tool to detect the monkeys' presence.

Mexico outputs $1.1 \%$ of world global cocoa production; and the state of Tabasco contributes $70 \%$ of the national production (Córdova-Avalos et al., 2008; Morales et al., 2012). In Tabasco, most of the cocoa plantations are located on Comalcaco, these are between 30 to 40 years old, with an average yield of $94.26 \mathrm{~kg} / \mathrm{ha}$ (De La CruzLandero et al., 2015). The producers that live on their farms in these agrosystems employ family labor, so local knowledge can be valuable to obtain information about 
species presence and abundance (Anadón et al., 2009). Mammals such as the mantled howler monkey (A. palliata) is one of the few species that inhabit these cocoa farms planted more than 40 years ago (Muñoz et al., 2006; Sánchez-Gutiérrez et al., 2016).

In southeast México, the mantled howler monkey (A. palliata) is a species with populations in danger of extinction due to habitat loss, according to Federal Law (Sernapam NOM-059; Jasso-Del Toro et al., 2016). Moreover, the red list of the International Union for the Conservation of Nature (IUCN) considers A. palliata mexicana as Critically Endangered. Today, some of these howler monkey populations live in fragmented forests, agrosystems, ecotourism sites and other modified landscapes, being valuable populations for conservation studies (Garber et al., 2015). Due to the change of their original habitats, this species is adapting to exploit small fragments of habitats such as coffee and cocoa agrosystems (Arroyo-Rodríguez and Días, 2010). In Tabasco, Mexico, some studies have reported the presence of howler monkeys in cocoa agrosystems (Vidal-García and Serio-Silva, 2011; ValenzuelaCórdova et al., 2015; Pozo-Montuy and Serio-Silva, 2006; Muñoz et al., 2006).

Howler monkeys consume a diet based on young leaves (suckers) and flowers most of the year, when there is shortage of fruits or seeds (Chaves and Bicca-Marques, 2016). Thus, their displacement during the different seasons of the year is attributed to vegetation phenology, that determines their food availability (Pozo-Montuy and SerioSilva, 2006; Yiming, 2006). The fact that these monkeys had to adapt to anthropogenic disruption, which lead to the fragmentation and loss of their habitats, and negative effects on vegetation, has important implications regarding their conservation (Pyritz et al., 2010).

The objective of this research was to identify the most robust spectral vegetation index, associating certain phenological characteristics of the vegetation (leaf area index, biomass and high chlorophyll content of leaves), to determine the presence of mantled howler monkeys (A. palliata) in the canopy of trees in cocoa agrosystems $(T$. cacao) in Tabasco, Mexico.

\section{Material and methods}

\section{Study area}

This study was carried out in three different cocoa agrosystems (Figure 1), in the town of Comalcalco in the State of Tabasco, Mexico. This is an area of approximately 72,319 ha of which 11,055 ha are cocoa plantations (15.2\%) (INEGI, 2012).

\section{Set of satellite data used}

A set of available images were reviewed, we looked for non-cloudy images, outside of cocoa pruning period and collected data on monkey presence every time on the same date (or as close as possible). As a result two Landsat-5 TM satellite images were chosen. These images were used on each study site to look for differences among vegetation indices associated with the presence of howler monkeys (Table 1). They were taken from the same season, since data from different seasons generated errors related to differences in reflectance values for the same vegetation type due to phenology. 


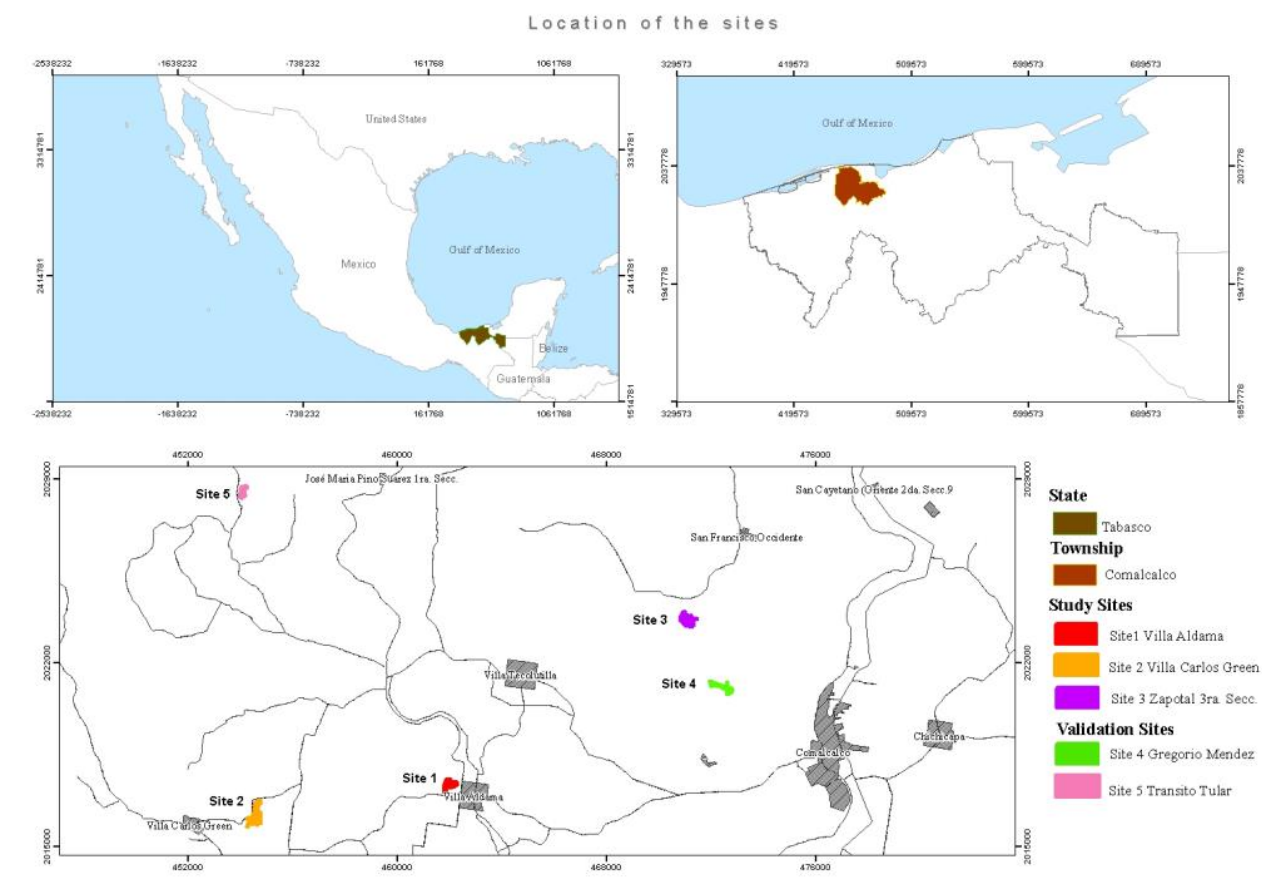

Figure 1. Cocoa agrosystems used as study sites

Table 1. Satellite data used in the study

\begin{tabular}{c|c|c|c|c|c}
\hline No. & Satellite & Sensor & $\begin{array}{c}\text { Date of } \\
\text { Acquisition }\end{array}$ & Path/Row & Source \\
\hline 1 & Landsat-5 & TM & $02-21-1997$ & $22-47$ & https://earthexplorer.usgs.gov/ \\
2 & Landsat-5 & TM & $02-28-2011$ & $22-47$ & https://earthexplorer.usgs.gov/ \\
\hline
\end{tabular}

\section{Presence and absence collection data}

A sample of proportions was used to ensure the largest sample size, it is considered as the maximum variance, with a precision of $\leq 0.05$ and a reliability of $95 \%$. For security purposes, $9 \%$ was added to the sample size obtained. To select the study sites, a survey was sent to 38 cocoa producers during February 2017, along with a compilation of presence and absence records of howler monkeys. Five study sites were selected (cocoa agrosystems) (Figure 2).

To have an estimate of the population structure, data of presence was recorded by direct observation. For each group, information was collected on the number of individuals, sex composition and type of substrate used (tree species).

The Laboratory of Landscape Ecology and Global Change at Juarez Autonomous University of Tabasco has records of howler monkeys on this agrosystems since 2001. On this investigation three different cocoa agrosystems were chosen as study sites: Site 1 (absence-presence) based on the survey, aimed to find in which site the specie was absent in 1997 and present in 2011, Site 2 (Presence-Presence) based on data from personal communication conducted by Valenzuela in June 2016, in which they report that the species has always been present, and Site 3 (Absence-Absence) from the article that published a model made by Vidal-García and Serio-Silva (2011) in which they 


$$
-1283 \text { - }
$$

report that according to the results of the model, the species has never been present on that site (Table 2, Figure 3) (CNES, 2012).

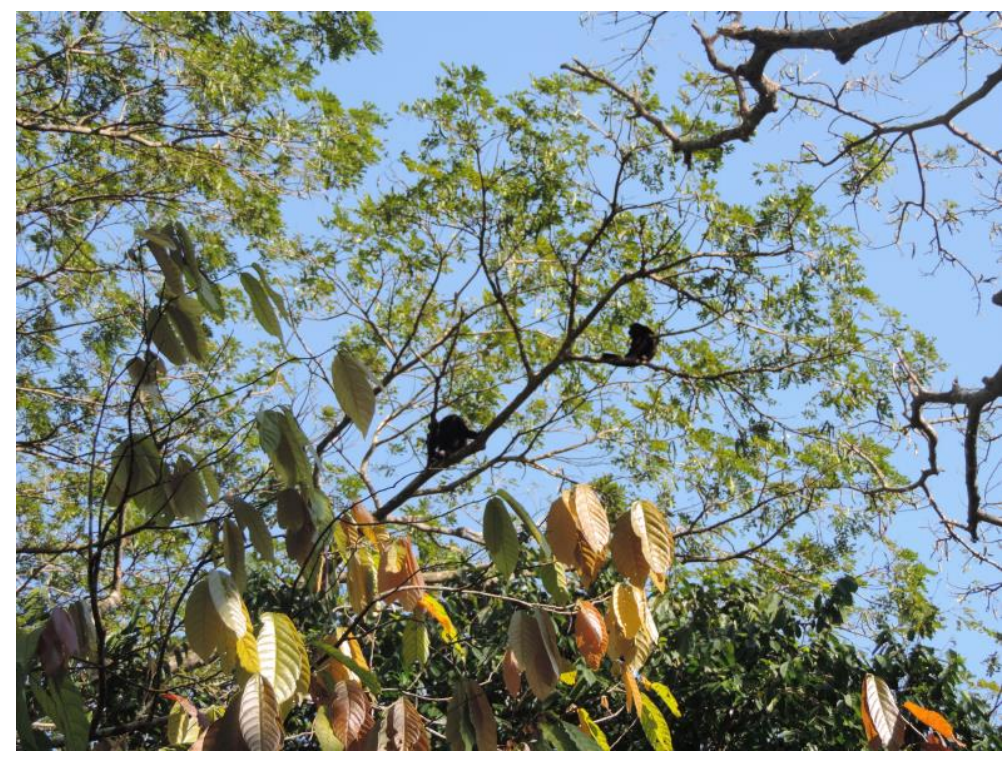

Figure 2. Monkeys in cocoa agrosystems

Table 2. Comparative data within the study sites

\begin{tabular}{c|c|c|c|c|c}
\hline \multirow{2}{*}{ Study Sites } & \multirow{2}{*}{ Location } & \multicolumn{2}{|c|}{ Coordinates (UTM) } & \multirow{2}{*}{ Remark } & Source \\
\cline { 3 - 4 } & Villa Aldama & 461830 & 2017193 & Absence-Presence & $\begin{array}{c}\text { Survey conducted, 2017 } \\
\text { Valenzuela, personal } \\
\text { communication, June } \\
\text { Site 1 }\end{array}$ \\
Site 2 & Villa Carlos G. & 454416 & 2016030 & Presence-Presence \\
Site 3 & Zapotal 3ra. S. & 471172 & 2023367 & Absence-Absence & $\begin{array}{c}\text { Vidal-García and Serio- } \\
\text { Silva, 2011 }\end{array}$ \\
\hline
\end{tabular}

\section{Limits of study sites}

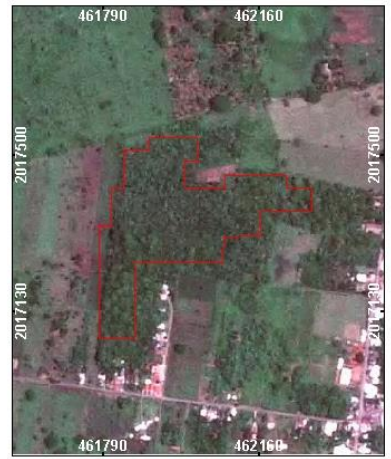

Site 1 Villa Aldam a

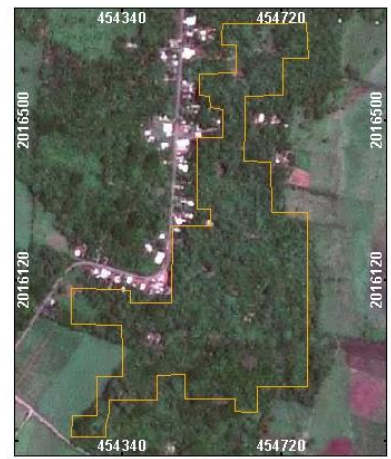

Site 2 Villa Carlos Green

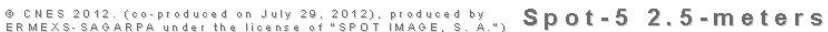

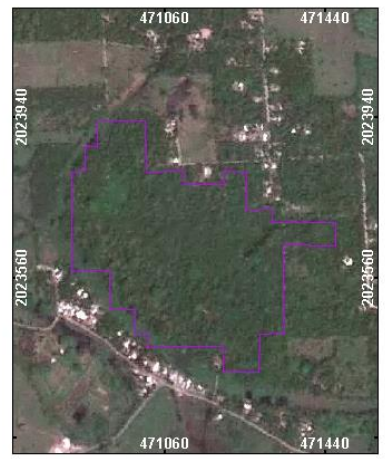

Site 3 Zapota

Figure 3. Maps of the study sites 
To validate the results, two other cocoa agrosystems were selected: Site 4 (absenceabsence) (Vidal-García and Serio-Silva, 2011), and Site 5 (presence-presence) (Valenzuela-Córdova et al., 2015) (Table 3, Figure 4) (CNES, 2012).

Table 3. Comparative data within the validation sites

\begin{tabular}{c|c|c|c|c|c}
\hline \multirow{2}{*}{ Study Sites } & \multirow{2}{*}{ Location } & \multicolumn{2}{|c|}{ Coordinates (UTM) } & \multirow{2}{*}{ Remark } & Source \\
\cline { 3 - 5 } & X & Y & Absence- & $\begin{array}{c}\text { Vidal-García and } \\
\text { Serio-Silva, 2011 } \\
\text { Site 4 }\end{array}$ \\
Site 5 & $\begin{array}{c}\text { Méndez } \\
\text { Transito Tular }\end{array}$ & 472050 & 2021184 & $\begin{array}{c}\text { Absence } \\
\text { Presence- } \\
\text { Presence }\end{array}$ & $\begin{array}{c}\text { Valenzuela-Córdova } \\
\text { et al., 2015 }\end{array}$ \\
\hline
\end{tabular}

\section{Limits of validation sites}

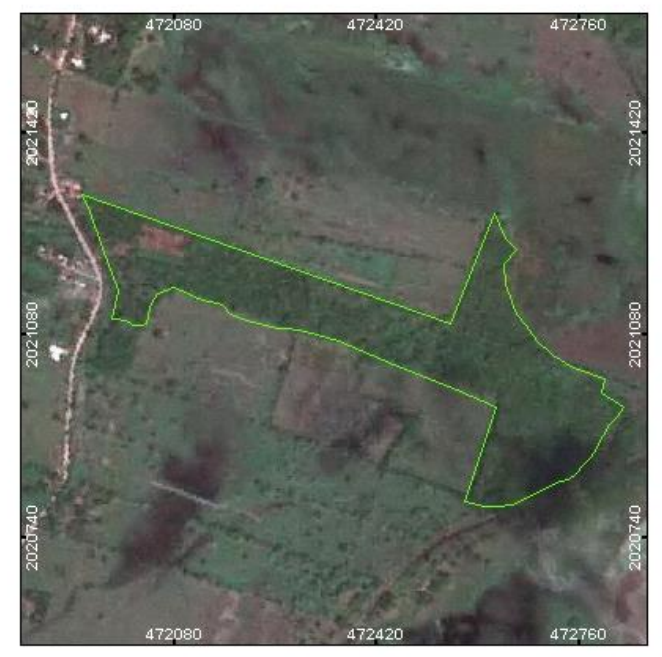

Site 4 Gregorio Mendez

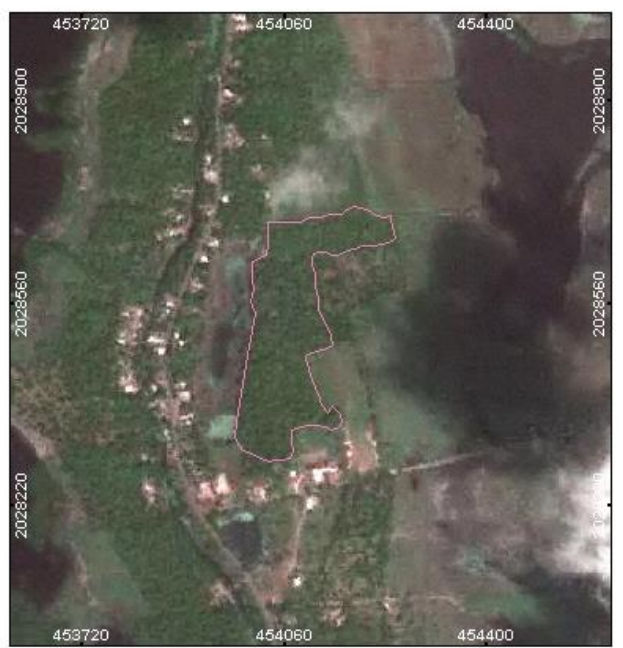

Site 5 Transito Tular

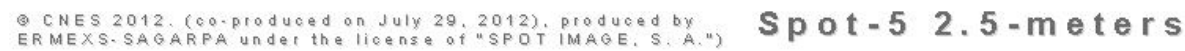

Figure 4. Site maps selected for validation

\section{Pre-processing of satellite images}

Images require the correction of possible radiometric and atmospheric distortions in the radiance values that are register by the sensor surveying the earth surface. For geometrical correction, the images were orthorectified using control points for the Landsat-5 TM scenes, using orthophotos at scale 1:15000, through software ArcGIS v 9.2. Radiometric and atmospheric corrections were made with the Idrisi TerrSet software.

\section{Spectral vegetation indices}

Nine vegetation indices were calculated for the multispectral images processed. The indices described below were selected based on literature reports that associate them with vegetation characterization. 


\section{Normalized Difference Vegetation Index (NDVI)}

Normalized Difference Vegetation Index (Equation 1) was introduced by Rouse et al. (1974). The combination of its normalized difference formulation and the use of higher chlorophyll absorption and reflection regions make it robust in a wide range of conditions. It is highly correlated to the leaf area index (IAF).

$$
N D V I=N I R-R / N I R+R
$$

\section{Ratio Vegetation Index (RVI)}

Ratio Vegetation Index (Equation 2) was suggested by Jordan (1969). The ratio of highest reflectivity by absorption of chlorophyll makes it easy to understand and is effective in a wide range of conditions. It has a high correlation with the Leaf Area Index, biomass and high chlorophyll content of leaves.

$$
R V I=N I R / R
$$

\section{Soil-Adjusted Vegetation Index (SAVI)}

Soil-Adjusted Vegetation Index (Equations 3) was proposed by Huete (1988). Minimizes variations induced by the brightness of the soil. L is a correction factor ranging from 0 (for very high vegetation cover) to 1 (for very low vegetation cover). The most commonly used value is $\mathrm{L}=0.5$, which is for intermediate vegetation cover. It is a modification of the NDVI to explain areas with low vegetation cover (i.e. <40\%).

$$
S A V I=N I R-R /(N I R+R+L) *(1+L)
$$

\section{Enhanced Vegetation Index (EVI)}

Enhanced Vegetation Index (Equation 4) was developed by Huete et al. (2002). It is an improvement on NDVI to better take into account soil background and the effects of atmospheric aerosols. The coefficients adopted in the MODIS-EVI algorithm are: $\mathrm{L}=1$, $\mathrm{C} 1=6, \mathrm{C} 2=7,5$. EVI requires a blue band and is sensitive to variations in blue band reflection, which limits the consistency of this index through different sensors.

$$
E V I=2.5 * N I R-R /(N I R+C 1 * R-C 2 * B * L)
$$

\section{Second Modified Soil Adjusted Vegetation Index (MSAVI2)}

Second Modified Soil Adjusted Vegetation Index (Equation 5) was suggested by Qi et al. (1994). Particularly important for areas that have different brightness coefficients of soil. Eliminates the need for user specification of $\mathrm{L}$.

$$
\text { MSAVI2 }=\left[2 * N I R+1-\left((2 * N I R+1)^{2}-8 *(N I R-R)\right)\left({ }^{1 / 2}\right)\right] / 2
$$

\section{Transformed Vegetation Index (TVI)}

Transformed Vegetation Index (Equation 6) was proposed by Deering et al. (1975). This index is designed to eliminate NDVI negative values and stabilize variance. 


$$
T V I=[\sqrt{\mathrm{NIR}-\mathrm{R} / \mathrm{NIR}+\mathrm{R}]}+0.5
$$

Perpendicular Vegetation Index (PVI)

Perpendicular Vegetation Index (Equation 7) was suggested by Richardson and Wiegand (1977). It uses the perpendicular distance of each pixel to the ground line. Whether the pixel corresponds to soil or vegetation depends on the distance of each pixel from the ground line. By taking into account the reflectivity of the soil, it isolates the information provided by vegetation.

$$
P V I=[N I R-a * R-b] /\left[\sqrt{1+a^{2}}\right]
$$

\section{Modified Soil Adjusted Vegetation Index (MSAVI1)}

Modified Soil Adjusted Vegetation Index (Equation 8) was suggested by Qi et al. (1994). The vegetation estimate uncertainty is reduced from $+2.5 \%$ (SAVI) to $+1.6 \%$ (MSAVI1). It is similar to WDVI in reducing soil noise, but its vegetation index values are higher.

$$
M S A V I 1=[N I R-R / N I R+R+L](1+L)
$$

\section{Ashburn Vegetation Index (AVI)}

Ashburn Vegetation Index (Equation 9) was proposed by Ashburn (1978). A strong influence of the underlying surface and atmosphere. Soil areas are well visible. Is computed following this equation:

$$
A V I=2 * N I R-R
$$

\section{Statistical analysis of vegetation indices}

A completely randomized design was used for each of the three study sites, with ten repetitions per vegetation index. The data was analyzed using PROC GLM from SAS. For the analysis of vegetation indices, NDVI, RVI, EVI, TVI, PVI, AVI, SAVI, MSAVI1, and MSAVI2 to determine significant differences between the indices. The multiple comparisons of treatment means were performed by Tukey Test $(\alpha=0.05)$.

\section{Spectral separability analysis}

The standard distance was applied to detect changes in vegetation (Kaufman and Remer, 1994) in order to identify the vegetation index with greater spectral separability in relation to the presence or absence of A. palliata in cocoa agrosystems (Equation 10).

$$
M=\left(\mu_{a}-\mu_{b}\right) /\left(\sigma_{a}+\sigma_{b}\right)
$$

$\mu_{\mathrm{a}}, \mu_{\mathrm{b}} \rightarrow$ Sample means for the presence (a) and absence (b) categories.

$\sigma_{a}, \sigma_{b} \rightarrow$ Standard deviation of samples for classes $a$ and $b$.

If the value of $\mathrm{M}$ is greater than one, it indicates good separability. 
The study compared the three sites: Site 1 (Absence-Presence), Site 2 (PresencePresence), and Site 3 (Absence-Absence), in the whole time period between the dates of the satellite images (02-21-1997 and 02-28-2011) recorded by Landsat-5 TM.

\section{Data analysis for independent mean comparison}

Parametric statistical tests were carried out to establish significant differences between the values of each index in cocoa agrosystems. Student's T-test was applied for two independent samples.

In this case, two hypotheses were raised:

- H0: There is no significant difference between the vegetation index values for each cocoa agrosystem, so all groups are equal and do not differ from each other.

- H1: There are significant differences between the vegetation index values for each cocoa agrosystem.

The significance level is $5 \%$, i.e. for any probability value (p-value) less than or equal to 0.05 means statistically significant differences. However, if it is greater than 0.05 , they are statistically equal.

\section{Validation}

A survey with cocoa producers was conducted to validate presence-absence of howler monkeys during the time period of our study (1997 and 2011). We corroborated whether statistically obtaining significant differences in the vegetation indices associated with the presence of howler monkeys in cocoa agrosystems have been due to anthropogenic or natural activities, such as fires, pests or pruning of cocoa.

\section{Index statistics with better spectral separability in the study sites}

Records of A. palliata were collected to observe presence of the species according to the values obtained from the RVI. There was no land use change at the study sites, so another ten images of Landsat-8 OLI / TIRS were used to complete the seasons of the year for the vegetation phenology analysis (Table 4), From February to April there were dry periods, it was rainy from May to October and, winter storms were detected from November to January. The ArcGis v 9.2 software was used to calculate the maximum and minimum value of the RVI index for each study site by season.

Table 4. Satellite data used to calculate RVI index values in the study sites

\begin{tabular}{c|c|c|c|c|c}
\hline No. & Satellite & Sensor & $\begin{array}{c}\text { Date of } \\
\text { Acquisition }\end{array}$ & Path/Row & Source \\
\hline 1 & Landsat-8 & OLI/TIRS & $25-01-2016$ & $22-47$ & https://earthexplorer.usgs.gov/ \\
2 & Landsat-8 & OLI/TIRS & $28-02-2017$ & $22-47$ & https://earthexplorer.usgs.gov/ \\
3 & Landsat-8 & OLI/TIRS & $08-03-2014$ & $22-47$ & https://earthexplorer.usgs.gov/ \\
4 & Landsat-8 & OLI/TIRS & $01-04-2017$ & $22-47$ & https://earthexplorer.usgs.gov/ \\
5 & Landsat-8 & OLI/TIRS & $19-05-2017$ & $22-47$ & https://earthexplorer.usgs.gov/ \\
6 & Landsat-8 & OLI/TIRS & $25-06-2013$ & $22-47$ & https://earthexplorer.usgs.gov/ \\
7 & Landsat-8 & OLI/TIRS & $03-07-2016$ & $22-47$ & https://earthexplorer.usgs.gov/ \\
8 & Landsat-8 & OLI/TIRS & $07-08-2017$ & $22-47$ & https://earthexplorer.usgs.gov/ \\
9 & Landsat-8 & OLI/TIRS & $03-09-2015$ & $22-47$ & https://earthexplorer.usgs.gov/ \\
10 & Landsat-8 & OLI/TIRS & $24-12-2015$ & $22-47$ & https://earthexplorer.usgs.gov/ \\
\hline
\end{tabular}




\section{Results}

\section{Description of the study sites and population structure of mantled howler monkeys}

From the 38 surveys carried out on cocoa producers, 64\% were sites of absence and only $36 \%$ recorded the presence of the species. $100 \%$ of producers have lived in their cocoa farms for more than 40 years. The owners of the sites with record of absence mentioned that species had never been present. The owners of the sites with record of presence said that species had been seen in the past for more than 30 years in their ranches, this is due to the fact that in the last 50 years $90 \%$ of their original habitats have been lost (Pozo-Montuy et al., 2015), and the monkeys took refuge in the cocoa agrosystems. In addition, they pointed out that as long as they are the owners of the farms, they will continue to grow cocoa. However, they warned that new generations could make a change in land use, in addition, because of climate variability, it is expected that a large amount of land suitable for cultivation will be lost due to floods and droughts (Saldarriaga, 2016). Local people attributed the presence of howler monkeys in their ranch to the diversity of fruit trees of which they eat, such as: zapote (Pouteria sapota), orange (Citrus sinensis), mango (Mangifera indica), chestnut (Artocarpus altilis), and nance (Byrsonima crassifolia), among others, as well as trees that monkeys use as a place of refuge, like: erythrina (Erythrina poeppigiana), palo Mulato (Bursera simaruba) and rain tree (Samanea saman), since they prefer to consume young leaves and ripe fruits due to their protein concentration (Anaya-Lira et al., 2013). However, they mentioned that howler monkeys do not cause any damage to their plantations since monkeys do not eat cocoa. In addition, on the survey sites there are also forest trees, such as: cedro (Cedrela odorata), macuilis (Tabebuia rosea), and caoba (Swietenia macrophylla), among others, that are useful for both people and monkeys (Sanchez-Gutiérrez et al., 2016). Through the survey, the producers stated that between 1997 and 2011 no deforestation has occurred on their land, only pruning takes place at the beginning of the rainy season in May (Matey et al., 2013), so there was no ongoing anthropogenic alteration in the images used from February. They also reported, that they have not had any type of alteration in their vegetation due to any plague or fire. However, climate variability is a proven fact, so they will have different effects in each geographical area or study site (Gallegos, 2017), as the phenology of the plants during flowering is strongly determined by climatic parameters such as temperature and precipitation (Adjaloo et al., 2012), which causes variability in different season of the year. In total, 50 individuals of monkeys were recorded among three communities of Comalcalco, in cocoa agrosystems between 30 and 40 years of age (Table 5).

\section{Statistical analysis of vegetation indices}

TVI, AVI, PVI and RVI indices are ungrouped because they have statistically significant differences. On the other hand, on "C" group, SAVI and MSAVI1 did not show statistically significant differences between them, and the same is true for group "E" with NDVI, MSAVI2 and EVI. Therefore, an index of each group was chosen: NDVI and SAVI since both are highly correlated with changes in vegetation and leaf area index (Ali et al., 2013) (Table 6). 


$$
-1289 \text { - }
$$

Table 5. Number of individuals per troop and shade trees in which they were found

\begin{tabular}{|c|c|c|c|c|c|}
\hline Site & Area & $\begin{array}{c}\text { Age of cocoa } \\
\text { plantation (years) }\end{array}$ & $\begin{array}{l}\text { Main plant species used } \\
\text { for shadow }\end{array}$ & Observed & $\begin{array}{c}\text { Number of observed } \\
\text { monkey (sex-age-structure) }\end{array}$ \\
\hline 1 & $14.36 \mathrm{ha}$ & 40 & $\begin{array}{c}\text { Cedrela odorata } \\
\text { Tabebuia rosea } \\
\text { Erythrina poeppigiana } \\
\text { Pouteria sapota } \\
\text { Artocarpus altilis } \\
\end{array}$ & Presence & $\begin{array}{c}25 \\
(3 \mathrm{am}, 10 \mathrm{af}, 8 \mathrm{j}, 4 \mathrm{i})\end{array}$ \\
\hline 2 & 28.45 ha & 38 & $\begin{array}{c}\text { Cedrela odorata } \\
\text { Tabebuia rosea } \\
\text { Bursera simaruba } \\
\text { Citrus sinensis } \\
\text { Byrsonima crassifolia }\end{array}$ & Presence & $\begin{array}{c}17 \\
(2 \mathrm{am}, 7 \mathrm{af}, 4 \mathrm{j}, 4 \mathrm{i})\end{array}$ \\
\hline 3 & 22.31 ha & 35 & $\begin{array}{c}\text { Tabebuia rosea } \\
\text { Castilla elástica } \\
\text { Swietenia macrophylla }\end{array}$ & Absence & 0 \\
\hline 4 & $15.45 \mathrm{ha}$ & 30 & $\begin{array}{c}\text { Swietenia macrophylla } \\
\text { Colubrina arborescens } \\
\text { Gliricidia sepium }\end{array}$ & Absence & 0 \\
\hline 5 & 12.21 ha & 35 & $\begin{array}{c}\text { Cedrela odorata } \\
\text { Tabebuia rosea } \\
\text { Samanea saman } \\
\text { Mangifera indica }\end{array}$ & Presence & $\begin{array}{c}8 \\
(1 \mathrm{am}, 3 \mathrm{af}, 2 \mathrm{j}, 2 \mathrm{i})\end{array}$ \\
\hline $\begin{array}{l}a m= \\
a f=a \\
j=j u \\
i=i n\end{array}$ & $\begin{array}{l}\text { lult male } \\
\text { lit female } \\
\text { nile } \\
\text { at }\end{array}$ & & & & \\
\hline
\end{tabular}

Table 6. Mean comparison in vegetation indices. Mean values grouping on the same letter are not significantly different according to the Tukey test ( $p<0.05)$

\begin{tabular}{c|c|c|c}
\hline t Group & Means & $\mathbf{N}$ & Treatment \\
\hline A & 1.11137 & 10 & TVI \\
B & 0.84628 & 10 & AVI \\
C & 0.78736 & 10 & MSAVI1 \\
C & 0.76963 & 10 & SAVI \\
E & 0.75599 & 10 & MSAVI2 \\
E & 0.73657 & 10 & NDVI \\
E & 0.73415 & 10 & EVI \\
G & 0.59641 & 10 & PVI \\
H & 0.15372 & 10 & RVI \\
\hline
\end{tabular}

\section{Spectral separability analysis}

Values of $\mathrm{M}$ greater than one indicate good separability, therefore the index with the best spectral separability was RVI $(\mathrm{M}=1.050537248)$ compared to the other indices used (Table 7).

Table 7. Spectral separability index (M) for each index and study site

\begin{tabular}{c|c|c|c}
\hline Indices & Site 1 & Site 2 & Site 3 \\
\hline NDVI & -0.63563823 & -1.115936299 & -0.540739845 \\
RVI & 0.54863390 & 1.050537248 & 0.525442761 \\
TVI & -0.61003079 & -1.093998335 & -0.535439881 \\
PVI & -0.54863463 & -1.050525089 & -0.525443461 \\
AVI & -0.54863390 & -1.050526158 & -0.525442761 \\
SAVI & -0.61205795 & -1.098791537 & -0.53647433 \\
\hline
\end{tabular}




\section{Comparison of means of two populations with t-student}

The compared values of each index among cocoa agrosystems were: site 1 (AbsencePresence), and site 2 (Presence-Presence), the values obtained where TT $= \pm 2.2622$ and $\mathrm{FT}=3.18$ with $\alpha=0.05$ show that there is a statistically significant difference, whereas, in site 3 (Absence-Absence), they are statistically equal (Table 8).

\section{Validation}

According to the values calculated for the validation, for Site 4 (Absence-Absence) they are statistically equal, and for site 5 (Presence-Presence) there is a statistically significant difference (Table 9).

\section{$R V I$ index statistics in the study sites}

The estimation of chlorophyll content using RVI calculated from Landsat-8 OLI/TIRS images for each season per study site is shown in Figure 5. The chlorophyll content ranges were: dry season from 0.39 to 0.22 , rainy season from 0.42 to 0.22 , and winter storm season between 0.41 and 0.22 . Concerning the site where the animals were absent the values were lower with $0.20,0.21$, and 0.22 , respectively for each season (Table 10).

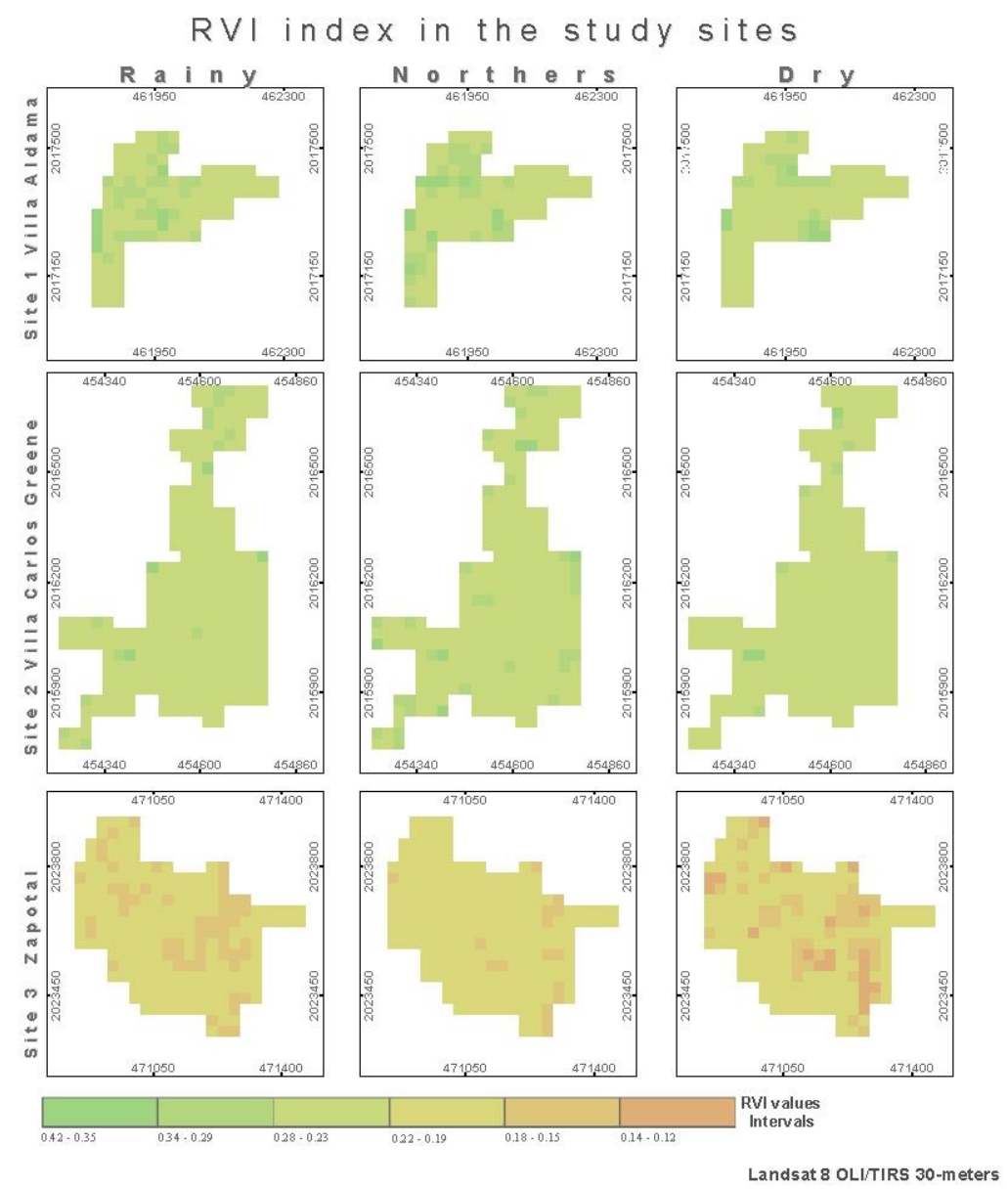

Figure 5. RVI values for the different seasons analyzed 
Table 8. Average comparison values for the NDVI, RVI, TVI, PVI, AVI and SAVI indices of LANDSAT-5 TM images

\begin{tabular}{c|cc|cc|cc}
\hline \multirow{2}{*}{ Indices } & \multicolumn{2}{|c|}{ Site 1 } & \multicolumn{2}{c|}{ Site 2 } & \multicolumn{2}{c}{ Site 3 } \\
& $\mathrm{t}$ Value & Value F & t Value & Value r F & t Value & Value F \\
\hline NDVI & 5.94 & $1.85^{*}$ & 5.04 & $2.45^{*}$ & 0.90 & 4.33 \\
RVI & -5.32 & $2.41^{*}$ & -4.48 & $3.15^{*}$ & -0.66 & 4.87 \\
TVI & 5.70 & $2.04^{*}$ & 4.90 & $2.64^{*}$ & 0.81 & 4.49 \\
PVI & 5.25 & $2.45^{*}$ & 4.52 & $3.15^{*}$ & 0.66 & 4.87 \\
AVI & 5.32 & $2.41^{*}$ & 4.52 & $3.15^{*}$ & 0.44 & 3.96 \\
SAVI & 5.77 & $2.00^{*}$ & 4.89 & $2.63^{*}$ & 0.83 & 4.43 \\
\hline
\end{tabular}

Table 9. Validation values of the mean comparisons

\begin{tabular}{c|cc|cc}
\hline \multirow{2}{*}{ Indices } & \multicolumn{2}{|c|}{ Site 4 } & \multicolumn{2}{c}{ Site 5 } \\
& t Value & Value F & 4.96 & Value F \\
\hline NDVI & -0.49 & 5.19 & -4.68 & $1.48^{*}$ \\
RVI & 2.23 & 4.09 & 4.87 & $2.18^{*}$ \\
TVI & -2.13 & 5.98 & 4.68 & $1.69^{*}$ \\
PVI & -1.90 & 4.35 & 4.68 & $2.18^{*}$ \\
AVI & -1.86 & 3.24 & 4.88 & $2.18^{*}$ \\
SAVI & -2.19 & 5.30 & $1.66^{*}$ \\
\hline
\end{tabular}

Table 10. Ranges of RVI relative to the presence and absence of the species

\begin{tabular}{c|c|c}
\hline Study site & Seasons & Range of RVI Values \\
\hline \multirow{3}{*}{1 (Presence) } & Dry & $0.35-0.22$ \\
& Rainy & $0.39-0.24$ \\
& Northers & $0.38-0.22$ \\
\hline \multirow{2}{*}{2 (Presence) } & Dry & $0.39-0.23$ \\
& Rainy & $0.42-0.22$ \\
& Northers & $0.41-0.23$ \\
\hline \multirow{2}{*}{ (Absence) } & Dry & $<0.20$ \\
& Rainy & $<0.21$ \\
\hline
\end{tabular}

\section{Discussion}

Due to fragmentation and habitat loss, primates have been forced to use agrosystems such as cocoa (Theobroma cacao) and coffee (Coffea arabica) plantations that grow under the shade of trees (Guzmán et al., 2016; Williams-Guillén et al., 2006). These agrosystems can act as the last habitat for species that tolerate a certain level of disturbance (Jasso-Del Toro et al., 2016; Muñoz et al., 2006). In the state of Tabasco, at the municipality of Comalcalco in particular, the mantled howler monkey (Aluatta palliata Mexicana), has been observed inhabiting cocoa agrosystems.

This study was carried out at an arboreal environment, between different sites with presence of the howler monkeys in cocoa agrosystems. An indirect method was used, considering the vegetation phenology as a metric to monitor biodiversity from space, as proposed by Skidmore et al. (2015). Through spectral vegetation indices, certain phenological characteristics of plant cover, such as density, leaf area index and 
chlorophyll activity were measured (Xue and $\mathrm{Su}, 2017)$. The spectral vegetation indices provide insight into habitat quality through vegetation phenology (Bradley and Fleishman, 2008). These metrics allow both calculating and relating healthy vegetation that can be used by monkeys, and can be used as an indicator of food availability to howler monkeys in cocoa agrosystems. Howler monkeys' diet is based on the associated shade trees and do not eat the cocoa fruit, therefore, the vegetation spectral indexes are an important tool to measure certain phenology characteristics from the shaded trees. Food availability will depend on the phenological state of the vegetation, which in this case is associated with the presence of the mantled howler monkey (A. palliata).

Similar studies have been conducted to determine the presence of other vertebrates, such as birds and mammals using spectral indices; although, they have been directly observed through the analysis of satellite images in open environments (not arboreal). For instance, flamingo populations (Sasamal et al., 2008), penguins (Fretwell et al., 2012), albatrosses (Fretwell et al., 2017), whales (Fretwell et al., 2014), polar bears (Stapleton et al., 2014), elephant seals (McMahon et al., 2014), gnus, zebras and gazelles (Yang et al., 2014; Xue et al., 2017). These vertebrates have been identified, located and even counted analyzing these satellite images.

This study detected difference between vegetation indices in cocoa agrosystems associated with the presence of mantled howler monkeys. The difference was determined by using the spectral separability of vegetation indices in three study sites. These vegetation indices have hardly been used on arboreal agrosystems. A study to evaluate the correlation between spectral indices to estimate biomass and carbon stock in cocoa and coffee agrosystems indicated that RVI and NDVI show significant differences (Bolfe et al., 2012). However, RVI was considered the best index, since it has a high correlation with leaf area index, biomass and chlorophyll (Coltri et al., 2013; $\mathrm{Xu}$ and $\mathrm{Su}, 2017)$.

In our research, a statistical analysis was used to identify the most robust spectral vegetation index, associated with the presence of the howler monkey (A. palliata) in arboreal environments such as cocoa agrosystems. The RVI index was the one that showed better spectral separability and statistically significant difference. Moreover, the displacement of howler monkeys could be related to the vegetation phenology estimated through the RVI index. The index detects changes on phenology among seasons through the year that can mean changes to food availability (Pozo-Montuy and Serio-Silva, 2006; Ramírez-Orjuela and Sánchez-Dueñas, 2005); although, the NDVI could also be considered as another good indicator of healthy vegetation. Some investigations suggest that there is a significant relation between the high values of NDVI and the presence of species, such as ostriches (Struthio camelus; Leyequien et al., 2007) and gnus (Connochaetes taurinus; Pettorelli et al., 2011). In the case of primates, the NDVI has been used to model the habitat of the vervet monkey (Cercopithecus aethiops) in Africa (Willems et al., 2009). The model indicates that monkeys prefer areas with high NDVI values as an indicator of food availability (green vegetation).

It has been suggested that the use of vegetation spectral signatures can serve as predictors of habitat condition on ecological niche analysis (López-Sandoval et al., 2015), allowing to improve the accuracy of these habitat models (Pettorelli et al., 2014). Nevertheless, some authors consider that these type of spectral signatures have relatively little use (He et al., 2015). The vegetation indices derived from the satellite images of our study area detected differences that can be considered as another variable, which can be used to predict the presence of the species. The different phenological 
stages of the vegetation (young leaves and ripe fruits) observed through the RVI index allow associating the presence of the monkeys in search of preferred food and identify their availability during the different seasons of the year. Therefore, these statistically representative indices could also be taken as variables or input parameters to predict habitats potentially suitable for monkeys through an ecological niche model for conservation purposes.

\section{Conclusions}

Howler monkeys are a viable subject for carrying out satellite image research in arboreal environments, due to their broad diet. They also had shown the capacity to adapt to small fragments of habitats, and currently have the need to take refuge in environments such as cocoa agrosystems, as the only arboreal habitat available in their vicinity. Their diet is based on the associated (shade) trees of the cocoa agrosystems. Since the monkeys do not eat the cocoa, they are not considered as an undesirable specie in plantations. The vegetation spectral indexes are an important tool to measure certain characteristics in the phenology of the associated trees, since the availability of food depends on the phenological state of the vegetation to a large extent, which in turn is associated with the presence of the mantled howler monkey ( $A$. palliata). The vegetation indices derived from the satellite images of our study area detected differences that can be considered as another variable to predict the presence of the species. The different phenological stages of the vegetation (young leaves and ripe fruits) observed through the RVI index allow associating the presence of the monkeys in search of preferred foods and identify their availability during the different seasons of the year. These statistically representative indices could also be taken as variables or input parameters to predict habitats potentially suitable for the presence of the species through an ecological niche model. They can be useful research tools to provide early warning of habitat change and promote timely response in support of decision makers to identify suitable environmental sites, and thus apply conservation efforts for primates and other species.

Acknowledgements. The authors are grateful to the Consejo Nacional de Ciencia y Tecnología de Mexico (CONACYT), for granting the scholarship for the research work.

\section{REFERENCES}

[1] Adjaloo, M. K., Oduro, W., Banful, B. K. (2012): Floral phenology of Upper Amazon cocoa trees: Implications for reproduction and productivity of cocoa. - ISRN Agronomy, ID461674: 1-8.

[2] Ali, M., Montzka, C., Stadler, A., Menz, G., Vereecken, H. (2013): Estimation and validation of leaf area index time series for crops on $5 \mathrm{~m}$ scale from space. - Geoscience and Remote Sensing Symposium 978: 3837-3840.

[3] Anadón, J. D., Giménez, A., Ballestar, R., Pérez, I. (2009): Evaluation of local ecological knowledge as a method for collecting extensive data on animal abundance. Conservation biology 23(3): 617-625.

[4] Anaya, J. A., Hernández, G. M. V. (2013): Phenology of the tropical environment in the context of remote sensing. - Geofocus: Revista Internacional de Ciencia y Tecnología de la Información Geográfica 13(2): 1578-5157. 
[5] Anaya-Lira, M., Gutiérrez-Olvera, C., Ducoing-Watty, A. M., Cifuentes-Calderón, P., Sánchez-Trocino, M. (2013): Voluntary consumption of fresh food by howler monkeys (Alouatta palliata and A. pigra) in captivity. - Cuadernos de Investigación UNED 5(1): 151155.

[6] Arroyo-Rodríguez, V., Días, P. A. D. (2010): Effects of habitat fragmentation and disturbance on howler monkeys: a review. - American Journal of Primatology 72(1): 1-16.

[7] Ashburn, W. L., Schelbert, H. R., Verba, J. W. (1978): Left ventricular ejection fraction - a review of several radionuclide angiographic approaches using the scintillation camera. - Progress in cardiovascular diseases 20(4): 267-284.

[8] Avtar, R., Kumar, P., Oono, A., Saraswat, C., Dorji, S., Hlaing, Z. (2016): Potential application of remote sensing in monitoring ecosystem services of forests, mangroves and urban areas. - Geocarto International 32(8): 874-885.

[9] Becerra, M. R. (2007): Oil palm cultivation and biodiversity. - Boletín El Palmicultor 427: 2.

[10] Bellard, C., Bertelsmeier, C., Leadley, P., Thuiller, W., Courchamp, F. (2012): Impacts of climate change on the future of biodiversity. - Ecology letters 15(4): 365-377.

[11] Benayas, J. R. (1993): Perspectives of remote sensing in ecological research. - Revista de teledetección: Revista de la Asociación Española de Teledetección (2): 4.

[12] Bolfe, É. L., Batistella, M., Ferreira, M. C. (2012): Correlation of spectral variables and aboveground carbon stock of agroforestry systems. - Pesquisa Agropecuária Brasileira 47(9): 1261-1269.

[13] Bradley, B. A., Fleishman, E. (2008): Can remote sensing of land cover improve species distribution modelling? - Journal of Biogeography 35(7): 1158-1159.

[14] Chaves, Ó. M., Bicca-Marques, J. C. (2016): Feeding strategies of brown howler monkeys in response to variations in food availability. - PloS One 11(2): e0145819.

[15] Chuvieco, E. (2016): Fundamentals of satellite remote sensing: An environmental approach. - CRC press, p468.

[16] CNES. (2012): (co-produced on July 29, 2012), produced by ERMEX-SAGARPA under the license of "SPOT IMAGE. S.A."

[17] Coltri, P. P., Zullo, J., do Valle Goncalves, R. R., Romani, L. A. S., Pinto, H. S. (2013): Coffee Crop's Biomass and Carbon Stock Estimation With Usage of High Resolution Satellites Images. - IEEE Journal of Selected Topics in Applied Earth Observations and Remote Sensing 6(3): 1786-1795.

[18] Corbane, C., Lang, S., Pipkins, K., Alleaume, S., Deshayes, M., Millán, V. E. G., Strasser, T., Borre, J. V., Toon, S., Michael, F. (2015): Remote sensing for mapping natural habitats and their conservation status-New opportunities and challenges. International Journal of Applied Earth Observation and Geoinformation 37: 7-16.

[19] Córdova-Avalos, V., Mendoza-Palacios, J. D., Vargas-Villamil, L., Izquierdo-Reyes, F., Ortiz-García, C. F. (2008): Participation of peasant organizations in the commercialization of cacao beans (Theobroma cacao L.) in Tabasco, Mexico. Universidad y ciencia 24(2): 147-158.

[20] De La Cruz-Landero, E., Córdova-Avalos, V., García-López, E., Bucio-Galindo, A., Jaramillo-Villanueva, J. L. (2015): Agricultural management and socioeconomic characterization of cocoa in Comalcalco, Tabasco. - Foresta veracruzana 17(1): 33-40.

[21] Deering, D. W., Rouse, J. W., Haas, R. H., Schell, J. A. (1975): Measuring 'forage production' of grazing units from Landsat MSS data. - Proceedings of the 10th International Symposium on Remote Sens. Environ 2: 1169-1178.

[22] Fretwell, P. T., La Rue, M. A., Morin, P., Kooyman, G. L., Wienecke, B., Ratcliffe, N., Fox, A. J., Fleming, A. H., Porter, C., Trathan, P. N. (2012): An emperor penguin population estimate: the first global, synoptic survey of a species from space. - PLoS One 7(4): e33751.

[23] Fretwell, P. T., Staniland, I. J., Forcada, J. (2014): Whales from space: counting southern right whales by satellite. - PLoS One 9(2): e88655. 
[24] Fretwell, P. T., Scofield, P., Phillips, R. A. (2017): Using super-high resolution satellite imagery to census threatened albatrosses. - Ibis 159(3): 481-490.

[25] Gallegos, J. A. F. (2017): Climate change indices in the Rio Sabinal basin, Chiapas, Mexico. - Tecnología y Ciencias del Agua 8(6): 137-143.

[26] Garber, P. A., Righini, N., Kowalewski, M. M. (2015): Evidence of alternative dietary syndromes and nutritional goals in the genus Alouatta. - In: Kowalewski, M. M., Garber, P. A., Cortés-Ortiz, L., Urbani, B., Youlatos, D. (eds.) Howler Monkeys. Springer 4: 85-109.

[27] Genc, H., Genc, L., Turhan, H., Smith, S. E., Nation, J. L. (2008): Vegetation indices as indicators of damage by the sunn pest (Hemiptera: Scutelleridae) to field grown wheat. African Journal of Biotechnology 7(2): 173-180.

[28] Giraldo, R. (2017): Study of the Spectral Signatures of Oil Palms Affected with Lethal Wilt, Using Functional Data Statistic Analysis. - Revista Palmas 37: 131-139.

[29] Guo, Q., Liu, J. (2018): Remote sensing has become an indispensable technology for biodiversity research protection and change monitoring. - Biodiversity Science 26(8): 785788.

[30] Guzmán, A., Link, A., Castillo, J. A., Botero, J. E. (2016): Agroecosystems and primate conservation: Shade coffee as potential habitat for the conservation of Andean night monkeys in the northern Andes. - Agriculture, Ecosystems \& Environment 215: 57-67.

[31] He, K. S., Bradley, B. A., Cord, A. F., Rocchini, D., Tuanmu, M. N., Schmidtlein, S., Turner, W., Wegmann, M., Pettorelli, N. (2015): Will remote sensing shape the next generation of species distribution models? - Remote Sensing in Ecology and Conservation 1(1): 4-18.

[32] Huete, A. R. (1988): A soil-adjusted vegetation index (SAVI). - Remote sensing of environment 25(3): 295-309.

[33] Huete, A., Didan, K., Miura, T., Rodriguez, E. P., Gao, X., Ferreira, L. G. (2002): Overview of the radiometric and biophysical performance of the MODIS vegetation índices. - Remote sensing of Environment 83(1): 195-213.

[34] INEGI. National Institute of Statistic and Geography. (2012): Perspectiva Estadística: Tabasco. - Instituto Nacional de Estadística y Geografía, Aguascalientes.

[35] Jasso-Del Toro, C., Márquez-Valdelamar, L., Mondragón-Ceballos, R. (2016): Genetic diversity in Mexican mantled howler monkeys (Alouatta palliata mexicana) at the Reserva de la Biosfera Los Tuxtlas (Veracruz, Mexico). - Revista Mexicana de Biodiversidad 87(3): 1069-1079.

[36] Jensen, J. R. (2007): Remote sensing of the Environment: An Earth Resource Perspective. - Pearson Prentice Hall. Upper Saddle River, NJ, p592.

[37] Jordan, C. F. (1969): Derivation of leaf-area index from quality of light on the forest floor. - Ecology 50(4): 663-666.

[38] Kaufman, Y. J., Remer, L. A. (1994): Detection of forests using mid-IR reflectance: an application for aerosol studies. - IEEE Transactions on Geoscience and Remote Sensing, 32(3): 672-683.

[39] Kerr, J. T., Ostrovsky, M. (2003): From space to species: ecological applications for remote sensing. - Trends in Ecology \& Evolution 18(6): 299-305.

[40] Lausch, A., Blaschke, T., Haase, D., Herzog, F., Syrbe, R. U., Tischendorf, L., Walz, U. (2015): Understanding and quantifying landscape structure-A review on relevant process characteristics, data models and landscape metrics. - Ecological Modelling 295: 31-41.

[41] Leong, M., Roderick, G. K. (2015): Remote sensing captures varying temporal patterns of vegetation between human-altered and natural landscapes. - PeerJ 3: e1141.

[42] Leyequien, E., Verrelst, J., Slot, M., Schaepman-Strub, G., Heitkönig, I. M., Skidmore, A. (2007): Capturing the fugitive: Applying remote sensing to terrestrial animal distribution and diversity. - International Journal of Applied Earth Observation and Geoinformation 9(1): 1-20. 
[43] López-Sandoval, J. A., López-Mata, L., Cruz-Cárdenas, G., Vibrans, H., Vargas, O., Martínez, M. (2015): Modeling of environmental factors that determine the distribution of synthropic species of physalis. - Botanical Sciences 93(4): 755-764.

[44] Loreto, D., Esperón-Rodríguez, M., Barradas, V. L. (2017): The climatic-environmental significance, status and socioeconomic perspective of the grown-shade coffee agroecosystems in the central mountain region of Veracruz, Mexico. - Investigaciones Geográficas, Boletín del Instituto de Geografía 92: 87-100.

[45] Matey, A., Zeledón, L., Orozco Aguilar, L., Chavarría, F., López, A., Deheuvels, O. (2013): Floristic composition and structure of cacao plantations and forest patches in Waslala, Nicaragua. - Agroforestería en las AméricasNúmero 49: 61-67.

[46] McMahon, C. R., Howe, H., van den Hoff, J., Alderman, R., Brolsma, H., Hindell, M. A. (2014): Satellites, the all-seeing eyes in the sky: counting elephant seals from space. PloS One 9(3): e92613.

[47] Morales, J. D. J., García, A., Méndez, E. (2012): What do you know about Cocoa? Revista Mexicana de Ciencias Farmacéuticas 43(4):79-81.

[48] Muñoz, D., Estrada, A., Naranjo, E., Ochoa, S. (2006): Foraging ecology of howler monkeys in a cacao (Theobroma cacao) plantation in Comalcalco, Mexico. - American Journal of Primatology 68(2): 127-142.

[49] Pettorelli, N., Ryan, S., Mueller, T., Bunnefeld, N., Jędrzejewska, B., Lima, M., Kausrud, K. (2011): The Normalized Difference Vegetation Index (NDVI): unforeseen successes in animal ecology. - Climate Research 46(1): 15-27.

[50] Pettorelli, N., Safi, K., Turner, W. (2014): Satellite remote sensing, biodiversity research and conservation of the future. - Phil. Trans. R. Soc. B 369: 20130190.

[51] Pozo-Montuy, G., Serio-Silva, J. C. (2006): Eating behavior of black howler monkeys (Alouatta pigra L) in fragmented habitat in Balacán, Tabasco, Mexico. - Acta zoológica mexicana 22(3): 53-66.

[52] Pozo-Montuy, G., Bravo-Bonilla, A., De la Cruz-Córdova, S., Torres-Flores, R., CruzCanuto I., Trejo-Bellido, M., Velázquez-Vázquez, G. (2015): UMA Management Plan in Free Life "The Cocoa Monkey" For the mantled howler monkey (Alouatta palliata mexicana). - Grupo de Biología para la Conservación S de RL de CV 76: 4-16

[53] Pyritz, L. W., Büntge, A. B., Herzog, S. K., Kessler, M. (2010): Effects of habitat structure and fragmentation on diversity and abundance of primates in tropical deciduous forests in Bolivia. - International journal of primatology 31(5): 796-812.

[54] Qi, J., Chehbouni, A., Huete, A. R., Kerr, Y. H., Sorooshian, S. (1994): A modified soil adjusted vegetation index. - Remote Sensing of Environment 48(2): 119-126.

[55] Ramírez-Orjuela, C., Sánchez-Dueñas, I. M. (2005): First Census of the Black Howler Monkey (Alouatta palliata aequatorialis) in El Chocó Colombian Biogeographic. Neotropical Primates 13(2): 1-7.

[56] Richardson, A. J., Wiegand, C. L. (1977): Distinguishing vegetation from soil background information. - Photogrammetric engineering and remote sensing 43(12): 1541-1552.

[57] Rocchini, D., Foody, G. M., Nagendra, H., Ricotta, C., Anand, M., He, K. S., Amici, V., Kleinschmit, B., Forster, M., Schmidtlein, S., Feilhaver, H., Ghisla, A., Metz, M., Neteler, M. (2013): Uncertainty in ecosystem mapping by remote sensing. - Computers \& Geosciences, 50: 128-135.

[58] Rouse Jr, J., Haas, R. H., Schell, J. A., Deering, D. W. (1974): Monitoring vegetation systems in the Great Plains with ERTS. - NASA special publication 351: 309-317.

[59] Saldarriaga, V. (2016): Effects of temperature variability on productivity and prices of agricultural products: evidence in Peru. - Inter-American Development Bank 1091: 9-33

[60] Sánchez-Gutiérrez, F., Pérez-Flores, J., Obrador-Olan, J. J., Sol-Sánchez, A., RuizRosado, O. (2016): Tree structure of pruning agroforestry system in Cárdenas, Tabasco, Mexico. - Revista Mexicana de Ciencias Agrícolas (14): 2695-2709. 
[61] Sasamal, S. K., Chaudhury, S. B., Samal, R. N., Pattanaik, A. K. (2008): QuickBird spots flamingos off Nalabana Island, Chilika Lake, India. - International Journal of Remote Sensing 29(16): 4865-4870.

[62] Skidmore, A. K., Pettorelli, N., Coops, N. C., Geller, G. N., Hansen, M., Lucas, R., Schaepman, M. E. (2015): Environmental science: agree on biodiversity metrics to track from space. - Nature 523: 403-405.

[63] Stapleton, S., LaRue, M., Lecomte, N., Atkinson, S., Garshelis, D., Porter, C., Atwood, T. (2014): Polar bears from space: assessing satellite imagery as a tool to track Arctic wildlife. - PloS One 9(7): e101513.

[64] Turner, W., Spector, S., Gardiner, N., Fladeland, M., Sterling, E., Steininger, M. (2003): Remote sensing for biodiversity science and conservation. - Trends in ecology \& evolution 18(6): 306-314.

[65] Turner, W., Rondinini, C., Pettorelli, N., Mora, B., Leidner, A. K., Szantoi, Z., Buchanan, G., Dech, S., Dwyer, J., Herold, M., Koh, L. P., Leimgruber, P., Taubenboeck, H., Wegmann, M., Wikelski, M., Woodcock, C. (2015): Free and open-access satellite data are key to biodiversity conservation. - Biological Conservation 182: 173-176.

[66] Valenzuela-Córdova, B., Mata-Zayas, E. E., Pacheco-Figueroa, C. J., Chávez-Gordillo, E. J., Díaz-López, H. M., Gama, L., Valdez-Leal, J. D. D. (2015): Ecotourism potential of the cacao (Theobroma cacao L) farming ecosystem with black howler monkeys (Alouatta palliata $\mathrm{G}$ ) in la Chontalpa, Tabasco. - Agroproductividad 8(5): 3-10.

[67] Vidal-García, F., Serio-Silva, J. C. (2011): Potential distribution of Mexican primates: modeling the ecological niche with the maximum entropy algorithm. - Primates 52(3): 261270.

[68] Wang, Y. Q., Zhou, Y., Wu, Z., Zhang, H., Zhang, J., Jin, Y., Huang, F., Yin, X. (2008): Monitoring landscape dynamics and conditions of natural resources within and adjacent to protected areas. - The International Archives of the Photogrammetry, Remote Sensing and Spatial Information Sciences 37: 1585-1590.

[69] Willems, E. P., Hill, R. A. (2009): A critical assessment of two species distribution models: a case study of the vervet monkey (Cercopithecus aethiops). - Journal of Biogeography 36(12): 2300-2312.

[70] Williams-Guillén, K., McCann, C., Martínez Sánchez, J. C., Koontz, F. (2006): Resource availability and habitat use by mantled howling monkeys in a Nicaraguan coffee plantation: Can agroforests serve as core habitat for a forest mammal? - Animal Conservation 9(3): 331-338.

[71] Willis, K. S. (2015): Remote sensing change detection for ecological monitoring in United States protected areas. - Biological Conservation 182: 233-242.

[72] Workie, T. G., Debella, H. J. (2018): Climate change and its effects on vegetation phenology across ecoregions of Ethiopia. - Global Ecology and Conservation 13: e00366.

[73] Xue, J., Su, B. (2017): Significant Remote Sensing Vegetation Índices: A Review of Developments and Applications. - Journal of Sensors 1353691: 1-17.

[74] Xue, Y., Wang, T., Skidmore, A. K. (2017): Automatic Counting of Large Mammals from Very High Resolution Panchromatic Satellite Imagery. - Remote sensing 9(878): 1-16.

[75] Yang, Z., Wang, T., Skidmore, A. K., de Leeuw, J., Said, M. Y., Freer, J. (2014): Spotting east African mammals in open savannah from space. - PloS One 9(12): e115989.

[76] Yiming, L. (2006): Seasonal variation of diet and food availability in a group of Sichuan snub-nosed monkeys in Shennongjia Nature Reserve, China. - American Journal of Primatology: Official Journal of the American Society of Primatologists 68(3): 217-233.

[77] Zhao, M., Peng, C., Xiang, W., Deng, X., Tian, D., Zhou, X., Yu, G., He, H., Zhao, Z. (2013): Plant phenological modeling and its application in global climate change research: overview and future challenges. - Environmental Reviews 21(1): 1-14. 